\title{
Evaluation of the "Kindergarten from Home" Programme during the COVID-19 Pandemic
}

\author{
Aleksandra Pajević ${ }^{1}$ \\ Preschool institution "Đurđevdan", Kragujevac, Serbia \\ Mirsen Fehratović \\ Psychology study programme, Department of Philosophical Sciences, State University of \\ Novi Pazar, Novi Pazar, Serbia
}

\begin{abstract}
The COVID-19 pandemic has resulted in major changes in education around the world. According to UNESCO, due to the adoption of precautionary measures to combat the spread of the disease, over 1.5 billion students and children experienced the interruption of formal education, which is the biggest simultaneous shock for all education systems. The international health crisis has led to radical, comprehensive and serious changes in the lives of both children and their parents. Also, COVID-19 has presented early education systems around the world with serious operational challenges. The preschool institution "Đurđevdan" in Kragujevac, respecting the rights of children and ensuring the principles of education and pedagogy, designed the programme "Kindergarten from Home". The research presented in this paper aims to investigate the satisfaction of parents and children with the "Kindergarten from Home" programme during the COVID-19 pandemic - to determine the attitudes and scope of participation of children and parents. The sample included 488 parents and 302 children. The results show that the activities: spending time together with the family (43\%), activities in the yard, nature (22\%), and activities for motor skills (10\%) produced the highest level of contentment in children. A large majority of children (73\%) are motivated to continue the "Kindergarten from Home" programme. A majority of parents and children (over 60\%) have given the "Kindergarten from home" programme the highest marks for interest and usefulness. The greatest percentage of the parents (42\%) consider the "activities for early literacy development" exceptionally important for their child and family, whereas almost a quarter of the parents consider "working habits" as such. More than half of the parents regularly participated in the activities of the programme "Kindergarten from Home". The programme will be continued with the goal of providing support to the education of children and their families, even after the normalization of the work of kindergarten, for all children who are prevented from attending kindergarten.
\end{abstract}

Keywords: kindergarten, COVID-19, preschool, parents, home.

1 aleksandrapajevic92@gmail.com 


\section{Introduction}

The COVID-19 pandemic has resulted in major changes in education around the world. According to UNESCO, due to the adoption of precautionary measures to combat the spread of the disease, over 1.5 billion students and children in 165 countries have experienced the discontinuation of regular formal education (UNESCO, 2020). Jamie Saavedra, Global Director of Education, describes it as "the greatest simultaneous shock to all education systems in our lives" (World Bank, 2020). As far as early childhood education is concerned, this international health crisis has led to radical, comprehensive and serious changes in the lives of both children and their parents. In addition to this, this crisis has affected both teachers and educators, regardless of whether they are actively teaching or preparing to work in that profession. COVID-19 has also brought early education systems around the world to the brink of collapse (Zero to Three, 2020).

Although COVID-19 is not a disease that often affects children, when all aspects that comprise the early development of a child are taken into account, the deeper implications of this global pandemic become obvious. The pandemic of the COVID-19 virus has not only suspended normal children's activities, such as attending kindergarten, hanging out with extended family and friends, playing outdoors and exploring nature, but has also disrupted the socio-emotional benefits that result from such experiences.

The children themselves are extremely vulnerable because meeting their most basic needs depends on adults. When these adults run out of ways to deal with the immediate, urgent and multiple demands for adaptation that the pandemic requires of families, and when support systems do not exist, give up or stop working, it can lead to extremely negative and long-term consequences for the youngest (Xafis, 2020).

Recent research has shown that children have more pronounced eating and sleeping disorders during the period when school is closed, they spend more time in front of the TV, phone or computer, have less physical activity, increased stress and less social interactions, all of which pose a risk to their physical and mental health (Wang, Zhang, Zhao, Zhang, \& Jiang, 2020). Among all the possible risks that school closure due to the COVID-19 virus epidemic poses to children's health, the United Nations Educational, Scientific and Cultural Organization (UNESCO) has listed "termination of education" as one of the main harmful consequences of school closure due to the COVID-19 pandemic (UNESCO, 2020). Formal education - whether on-site or remote - provides the basic knowledge and skills necessary for the further growth and development of children (UNESCO, 2020).

School and kindergarten closures have had numerous impacts on children's learning and development. Due to the implementation of measures restricting movement and imposing physical distance, the interaction of children with peers has been significantly reduced, which is especially important for preschool children. Important social skills and many developmental tasks of children are developed precisely through social interaction and playing with peers (Cameron \& Tenenbaum, 2021). Children learn and develop through play and interactions, because learning leads to development. According to the American Academy of Pediatrics, children who spend more time playing outdoors have better-developed motor and perceptual skills, are less prone to obesity, ADHD, and show less aggression, stress and depression. For this reason, it is suggested that children be 
allowed to play outside, while respecting measures and keeping physical distance (American Academy of Pediatrics, 2020 as cited in Goldschmidt, 2020).

Over the last three decades, a large number of studies have provided empirical evidence that a conducive environment for learning at home (HLE) is an important predictor of differences in children's academic and social development (Bandel, Vallotton, Luo, McFadden, \& Tamis-LeMonda, 2019; Rose, Lehrl, Ebert, \& Weinert, 2018). Children's participation in learning activities, the quality of the parent-child relationship, and the availability of learning materials are three key characteristics of a suitable home learning environment that help support children's educational development (Bradley \& Corwyn, 2002). Individual differences in literacy and numeracy skills are obvious when starting school - i.e. before formal teaching - which suggests that children acquire the most basic knowledge either at home or in kindergarten.

Today's children and youth are considered to be digital natives; they grew up not only with television, but also with increasingly advanced video games, fast computers, laptops and tablets, mobile phones, and with easy Internet access (Prensky, 2001). It is important for parents and educators to be careful and to strive for balance when using video games, laptops, and tablets (Ernest, Causey, Newton, Sharkins, Summerlin, \& Albaiz, 2014; Plowman, 2014).

One of the potential causes of partial or sporadic involvement of children in learning at home may be the idea that this type of learning is too challenging or uninteresting. Children and young people may lose all interest in learning if the very idea of learning from home presents some difficulty, or is not stimulating enough. Separation from peers can also lead to a loss of interest in learning (Smith, 1993).

Many formal education opportunities are not available due to the closure of schools and institutions caused by the COVID-19 pandemic. On the other hand, reading to children daily is a low-tech strategy for preventing certain negative consequences caused by the closure of schools and kindergartens due to the COVID-19 virus pandemic, while strengthening family ties (Biemiller \& Boote, 2006; Neuman, Copple, \& Bredekamp, 2000). Reading daily to young children helps compensate for some of the expected loss of reading ability caused during school closures due to the COVID-19 virus pandemic. Reading books to children at home is not a long-term solution for teaching reading to children who attend kindergarten; it cannot replace the key role that formal education - whether on-site or remote - provides (Castles, Rastle, \& Nation, 2018).

All of the aforementioned information points to the importance and necessity of finding a way to continue working with preschool children even when physical gathering in a preschool institution is not possible. We can say that COVID-19 has become an initiator for educational institutions around the world to find innovative solutions in a relatively short period of time (Stepanović, 2020).

These rapid changes in education have caused a certain level of inconvenience, but they have also shown new examples of innovation in education. Although it is too early to judge how COVID-19 will further affect the education system worldwide, there are indications that it could have a lasting impact on the development path of innovation in education and the digitalization process (Stepanović, 2020). 


\section{The "Kindergarten from Home" programme of the preschool institution "Đurđevdan" Kragujevac}

After the declaration of the state of emergency in the Republic of Serbia and the interruption of the regular work of preschool institutions, with the aim of further preventing the spread of the COVID-19 virus, it was necessary to ensure children's right to education (Zakon o osnovama sistema obrazovanja i vaspitanja, 2020, a. 3). Also, it was necessary to ensure the general principle of education, which refers to equality and accessibility of exercising the right to education based on social justice and the principle of equal opportunities without discrimination (Zakon o osnovama sistema obrazovanja i vaspitanja, 2020 , a. 7). In accordance with the Law on the Foundations of the Education System, the Ministry of Education, Science and Technological Development of the Republic of Serbia issued guidelines for the implementation of the work of preschool institutions during the closure due to the pandemic on 23 March 2020. The guidelines represent the response of the preschool education system during the COVID-19 pandemic, emphasising the priority activities: supporting families, preserving human health and safety, professional connections, networking and exchange of practitioners (Predškolstvo, 2020).

The preschool institution "Đurđevdan" Kragujevac designed the programme "Kindergarten from Home", by following the expert guidelines of the Ministry of Education, Science and Technological Development, simultaneously respecting the rights of children and ensuring the general principles of education which refer to equality and accessibility (Zakon o osnovama sistema obrazovanja i vaspitanja, 2020, a.3, 7).

"Kindergarten from Home" is an online community of support and exchange with families for the meaningful organization of time and activities in conditions of isolation of parents and children. The goals of the "Kindergarten from Home" programme are: to support the functioning of children and their families and to support the families to provide conditions for continuous learning through play. The online support community ("Kindergarten from Home") is organized through Viber groups with parents for each nursery, educational and preschool group. Educators and nurses-educators prepared proposals for joint activities of parents with children at home on a daily basis in accordance with the Kindergarten Annual Work Plan, and sent them to families via Viber groups. Activity examples: "Parents, listen to the song "April's jokes" together with your children. Then, ask the children what is funny to them and let them illustrate the answer", "Together with the children, make a polygon in the yard and organize competitive games", "Plant a plant. Discuss what is needed for its growth and development. Monitor the progress of the plant together with the child." Next, they encouraged the connection and exchange of experiences of children and their families, respecting the principle of voluntariness in terms of family participation in the Viber group. Respecting the principle of voluntariness, parents sent daily feedback via Viber groups about the proposed activities to educators and nurses-educators, and made suggestions for future activities.

The importance of "Kindergarten from Home" is evidenced by the fact that the family is the primary and most important educator of children and represents the first context in which children's learning and development takes place. It has several functions, and one of them is educational. According to Minić and Kompirović, the educational function of a child 
includes, at the earliest age, nutrition and care, health care, then preparation for successful inclusion in the social environment, laying the foundations for moral personality formation, creating hygienic and work habits, physical activity and acquiring new knowledge (Minić \& Kompirović, 2014). More precisely, the task of the family is to successfully influence the physical and mental development of the child. The role of institutional preschool education is to support families in achieving their educational function to build open communication with them, engage in dialogue and offer them information, counseling, ideas, suggestions for interconnection, joint participation of children and adults in various life-practical activities and play (Marković, Mamutović, \& Stanisavljević-Petrović, 2019).

\section{Research methodology}

The main aim of the research was to determine the satisfaction of parents and children with the "Kindergarten from Home" programme during the COVID-19 pandemic - determining the attitude and scope of participation of children and parents. A non-experimental method and a questionnaire were used in the research as a technique for data collection.

\section{Research instrument}

The questionnaire "Evaluation of the "Kindergarten from Home" programme by parents and children" was administered for the needs of research using the application Google Forms (for epidemiological reasons, it was not possible to conduct a paper-pencil survey).

The questionnaire consisted of 16 questions, 3 of which were intended for children (example item: "What did you like the most while playing at home?"), and were used to measure: satisfaction with the programme, initiative and motivation to continue the programme. The next 3 questions for parents and children were intended to assess: the interestingness and usefulness of the programme, and the connection with the kindergarten group. On a five-point Likert scale, they expressed a degree of agreement with the statements (example item: "Together with your child, evaluate how interesting the activities of kindergarten from home were: 1- not at all, 2- not much, 3-moderately, 4 - very, 5 - exceptionally"). There were also 13 questions for parents intended for the evaluation of: the importance of the programme, regularity of participation, reasons for non-participation, improvement of the programme and critical evaluation of the programme (example item: "Do you have suggestions for improving the work of "Kindergarten from Home?"). According to the structure, the questions were: open-ended, semi-open and closed-ended.

\section{Sample}

488 parents and 302 children participated in the research. Children were aged between three and six, with more than half being of preschool age (50.66\%).

\section{Research procedure}

The research was conducted during May 2020. It was done online - educators and nurses-educators forwarded the link to the questionnaire to all parents. Before complet- 
ing the questionnaire, the parents were introduced to the instructions, which stated that the research was completely anonymous and that the results would be used exclusively for research purposes. Since certain questions were intended for the children, the parents wrote down the answers as their child verbalized them.

\section{Data processing}

The research applied descriptive statistics and qualitative analysis for open-ended questions, where the answers of the respondents were placed in categories. The following are the results from the perspective of: the child, the child and the parent together, and the parent alone.

\section{Research results}

\section{Results from the perspective of the child}

The first question ("What did you like the most while playing at home?") intended for the children, referred to the assessment of the activities that caused the most sense of comfort at home.

Table 1

Activities that produced the highest level of contentment

\begin{tabular}{|c|c|c|}
\hline Categories & $\begin{array}{l}\text { Number of } \\
\text { responses (\%) }\end{array}$ & Example of a response \\
\hline $\begin{array}{l}\text { Spending time together } \\
\text { with the family }\end{array}$ & $130(43 \%)$ & $\begin{array}{l}\text { "What I liked the most is that we all participated in the games } \\
\text { as a family.; "That I spent more time with mom and dad." }\end{array}$ \\
\hline Activities in the yard, nature & $67(22 \%)$ & "That I planted flowers and took walks in nature." \\
\hline Activities for motor skills & $30(10 \%)$ & "Jumping on a trampoline, riding a bike and going down a slide." \\
\hline Drama activities & $21(7 \%)$ & $\begin{array}{l}\text { "When I was role-playing fairytale characters."; } \\
\text { "That mom acts as an educator." }\end{array}$ \\
\hline $\begin{array}{l}\text { Activities for developing } \\
\text { certain graphomotor skills }\end{array}$ & $15(5 \%)$ & "Drawing and writing with mom and dad." \\
\hline All activities & $39(13 \%)$ & "I liked everything that the educators sent us." \\
\hline Total & $302100 \%$ & \\
\hline
\end{tabular}

The results from Table 1 show that the greatest percentage of children's answers $(43 \%)$ refer to the category "spending time together with the family", which evoked the highest level of contentment. Meanwhile, almost a quarter of the children's answers (22\%) refer to "outdoor activites".

The next question ("Did you suggest a game / task to your friends and educators?") referred to the involvement and initiative of children in the "Kindergarten from Home" programme. The data show that $73(24 \%)$ children suggested activities in the programme "Kindergarten from Home" of the preschool institution "Đurđevdan" Kragujevac, while 229 (76\%) children did not have suggestions.

The following question examined children's motivation for the continuation of the "Kindergarten from Home" programme of the preschool institution "Đurđevdan" Kragujevac. 
Table 2

Children's motivation for the continuation of the "Kindergarten from home" programme of the preschool institution

"Eurdevdan" Kragujevac

\begin{tabular}{llcc}
\hline Question & \multicolumn{3}{c}{ Offered answers } \\
\hline Do you still want your educators to send you tasks & Yes & Not sure & No \\
\cline { 2 - 4 } and games to do at home? & $220(73 \%)$ & $45(15 \%)$ & $37(12 \%)$ \\
\cline { 2 - 4 } In total & & $302(100 \%)$ & \\
\hline
\end{tabular}

The results in Table 2 show that the greatest percentage of children (73\%) is motivated for the continuation of the "Kindergarten from Home" programme.

\section{Results from the perspective of the child and the parent together}

The questions intended for the children and the parents were related to the assessment of: interesting facts, usefulness of the "Kindergarten from Home" programme, as well as the feeling of connection with the kindergarten group.

Table 3

Evaluation of the "Kindergarten from Home" programme of the preschool institution "Durđevdan" Kragujevac.

\begin{tabular}{|c|c|c|c|c|c|}
\hline \multirow{2}{*}{$\begin{array}{l}\text { Question: Together with the } \\
\text { child evaluate how much the } \\
\text { activities of "Kindergarten from } \\
\text { Home" were: }\end{array}$} & \multicolumn{5}{|c|}{ Offered answers } \\
\hline & $\begin{array}{c}1 \\
\text { (not at all) }\end{array}$ & $\begin{array}{c}2 \\
\text { (not much) }\end{array}$ & $\begin{array}{c}3 \\
\text { (moderately) }\end{array}$ & $\begin{array}{c}4 \\
\text { (very) }\end{array}$ & $\begin{array}{c}5 \\
\text { (exceptionally) }\end{array}$ \\
\hline A) Interesting: & $2(0.2 \%)$ & $2(0.2 \%)$ & $50(10.2 \%)$ & $128(26.2 \%)$ & $306(62.7 \%)$ \\
\hline B) Useful: & $3(0.6 \%)$ & $5(1 \%)$ & $54(11.1 \%)$ & 111 (22.7\%) & 315 (64.5\%) \\
\hline $\begin{array}{l}\text { C) Contributed to being } \\
\text { connected with friends from } \\
\text { kindergarten: }\end{array}$ & $27(5.5 \%)$ & $32(6.6 \%)$ & $83(17 \%)$ & 101 (20.7\%) & $245(50.2 \%)$ \\
\hline In total 488 (100\%) & & & & & \\
\hline
\end{tabular}

The results in Table 3 show that the great majority of the parents and the children (over $60 \%$ ) evaluate as exceptional the interestingness and usefulness of the "Kindergarten from Home" programme. A slightly smaller number of parents and children 245 (50.2\%) assess the connection with the peer group, based on the proposed activities of the "Kindergarten from Home" programme as exceptional, while 101 (20.7\%) rate it as very good.

\section{Results from the perspective of the parent}

The first question ("Which activities from the "Kindergarten from Home" programme do you consider especially important for your child and family?"), intended exclusively for the parents, referred to the assessment of the importance of "Kindergarten from Home" activities for the child and the family. 
Table 4

Evaluation of the importance of the activities in the "Kindergarten from Home" programme

\begin{tabular}{lrl}
\hline Categories & $\begin{array}{c}\text { Number of } \\
\text { responses (\%) }\end{array}$ & \multicolumn{1}{c}{ Example of a response } \\
\hline $\begin{array}{l}\text { Activities for early literacy } \\
\text { development }\end{array}$ & $205(42 \%)$ & "Learning letters and numbers." \\
$\begin{array}{l}\text { Fine and gross motor skills } \\
64(13 \%)\end{array}$ & $\begin{array}{l}\text { "Games with continuing the string, games for stinging. } \\
\text { Games on the polygon in the backyard." }\end{array}$ \\
$\begin{array}{l}\text { Speech development } \\
\text { Creative learning }\end{array}$ & $29(6 \%)$ & $\begin{array}{l}\text { "Reading stories, poems and enriching chldren's vocabulary." } \\
\text { "Creative workshops where imagination is being mostly } \\
\text { developed." }\end{array}$ \\
Working habits & $107(22 \%)$ & $\begin{array}{l}\text { "The tasks they were given, so they can slowly learn that } \\
\text { completed at home." }\end{array}$ \\
All activities & $49(10 \%)$ & "All activities are equally important." \\
In Total & $488(100 \%)$ &
\end{tabular}

Table 4 shows us that the greatest percentage of parents (42\%) consider the "activities for early literacy development" as exceptionally important for their child and family, whereas almost a quarter of the parents consider "working habits" as such.

The following questions referred to the initiative and the activity of the parents in the "Kindergarten from Home" programme.

Table 5

The initiative and the activity of parents in the "Kindergarten from Home" programme

\begin{tabular}{lccc}
\hline \multirow{2}{*}{ Question } & \multicolumn{3}{c}{ Offered answers } \\
\cline { 2 - 4 } & Yes & No & Occasionally \\
\hline $\begin{array}{l}\text { "Did you participate in suggesting the activities in } \\
\text { the "Kindergarten from home programme"?" }\end{array}$ & $123(25 \%)$ & $243(50 \%)$ & $122(25 \%)$ \\
\hline Question & Regularly & Occasionally & I did not participate \\
\hline "I participated in the activities of"Kindergarten & $271(55 \%)$ & $205(42 \%)$ & $12(3 \%)$ \\
from home"?" & $488(100 \%)$ & & \\
In total & & & \\
\hline
\end{tabular}

The results in Table 5 show that a quarter of parents (25\%) initiated activities in the "Kindergarten from Home" programme, another quarter of parents (25\%) did so occasionally, while the largest percentage of parents (50\%) did not initiate activities in the "Kindergarten from Home" programme. Next, more than half of the parents (55\%) regularly participated in the activities of the "Kindergarten from Home" programme, while less than half of the parents (42\%) participated occasionally.

In addition, the parents who answered the previous question: "I did not participate in the "Kindergarten from Home" programme", had to select one of the offered reasons for non-participation or write their own. 
Table 6

Reasons for non-participation of parents in the "Kindergarten from Home" programme

\begin{tabular}{lcl}
\hline Categories & $\begin{array}{c}\text { Number of } \\
\text { responses (\%) }\end{array}$ & \multicolumn{1}{c}{ Example of a response } \\
\hline $\begin{array}{l}\text { Professional obligations } \\
\text { "Mresence of one or more }\end{array}$ & $98(20 \%)$ & $\begin{array}{l}\text { "My husband and I both work in a COVID outpatient clinic; } \\
\text { therefore, we weren't able to follow the activities." } \\
\text { "I have two more children, first- and second-graders, we were } \\
\text { busy with school work." } \\
\text { "Because of a baby, otherwise we practise, we just do it when } \\
\text { we have time." }\end{array}$ \\
$\begin{array}{l}\text { Children spending time at } \\
\text { their grandparents'house }\end{array}$ & $79(16 \%)$ & $\begin{array}{l}\text { "Her grandmothers were taking care of her, so we did } \\
\text { homework occasionally." }\end{array}$ \\
$\begin{array}{l}\text { Designing other activities } \\
\text { for the child } \\
\text { In Total }\end{array}$ & $37(8 \%)$ & "We use our ideas more for playing in nature." \\
\hline
\end{tabular}

Table 6 shows us that more than half of the parents state "professional obligations" as the reason for non-participation in the "Kindergarten from Home" programme, whereas 20\% of parents' answers state "presence of one or more siblings" as the reason for not participating. Thenextquestion ("Whatdidyouliketheleastinthe"Kindergartenfrom Home"programme?") referred to the critical assessment of the "Kindergarten from Home" programme.

Table 7

Critical evaluation of the "Kindergarten from home" programme

\begin{tabular}{|c|c|c|}
\hline Categories & $\begin{array}{l}\text { Number of } \\
\text { responses (\%) }\end{array}$ & Example of a response \\
\hline Too many offered activities & $190(39 \%)$ & $\begin{array}{l}\text { "Sometimes it happened that we couldn't manage to do all of the } \\
\text { activities because too many suggestions were offered." }\end{array}$ \\
\hline $\begin{array}{l}\text { Overly frequent messages } \\
\text { in Viber groups }\end{array}$ & $137(28 \%)$ & $\begin{array}{l}\text { "Too frequent messages and too many pictures (I think the } \\
\text { number should be limited to one, maximum two pictures and } \\
\text { we should suggest a time during the day when we all send } \\
\text { activities)." }\end{array}$ \\
\hline $\begin{array}{l}\text { Lack of materials for crea- } \\
\text { ting the proposed game }\end{array}$ & $54(11 \%)$ & $\begin{array}{l}\text { "Well, sometimes the only thing we would lack was the material, } \\
\text { but we had the opportunity to think and do differently." }\end{array}$ \\
\hline $\begin{array}{l}\text { All activities were } \\
\text { interesting }\end{array}$ & 107 (22 \%) & $\begin{array}{l}\text { "I liked everything. It saves time thinking about how to spend } \\
\text { quality time with your child through play." }\end{array}$ \\
\hline Total & $488(100 \%)$ & \\
\hline
\end{tabular}

The results in Table 7 show that the greatest percentage of the parents' answers (39\%) refer to the category "too many offered activities" as a critical evaluation of the "Kindergarten from Home" programme, while almost one third of the parents' answers refer to the category "overly frequent messages in Viber groups".

The next question ("Do you have any suggestions for improving the "Kindergarten from Home" programme?") was aimed at improving the functioning of the "Kindergarten from home" programme. 
Table 8

Improving the functioning of the "Kindergarten from Home" programme

\begin{tabular}{|c|c|c|}
\hline Categories & $\begin{array}{l}\text { Number of } \\
\text { responses (\%) }\end{array}$ & Example of a response \\
\hline $\begin{array}{l}\text { Creating a digital } \\
\text { platform }\end{array}$ & 205 (42 \%) & $\begin{array}{l}\text { "Create a Google classroom as with schoolchildren, so as to give the } \\
\text { children an opportunity to participate and discuss a topic live, just } \\
\text { how they would in the classroom." }\end{array}$ \\
\hline $\begin{array}{l}\text { Limited number of } \\
\text { activities }\end{array}$ & 146 (30 \%) & $\begin{array}{l}\text { "One activity for the whole week, and an exact time for sending } \\
\text { messages." }\end{array}$ \\
\hline $\begin{array}{l}\text { Innovative } \\
\text { activities, outdoor } \\
\text { activities. }\end{array}$ & $88(18 \%)$ & $\begin{array}{l}\text { "Introducing more new things, methods and techniques which will } \\
\text { be interesting for both children and parents, not just the common } \\
\text { ones." "Create more outdoor activities." }\end{array}$ \\
\hline $\begin{array}{l}\text { No suggestions for } \\
\text { improvement }\end{array}$ & 49 (10\%) & "We are satisfied with the current one - Kindergarten from Home." \\
\hline Total & 488 (100\%) & \\
\hline
\end{tabular}

The results in Table 8 show that almost half of the parents' answers (42\%) refer to the category "creating a digital platform" as a suggestion for improving the functioning of the "Kindergarten from Home" programme. Next, one third of the parents' answers refer to the category "limited number of activities" which would be sent through the Viber groups by the educators.

The final question intended for the parents ("Write down your general impression or comment about "Kindergarten from Home") referred to the general evaluation of the "Kindergarten from Home" programme.

Table 9

General impression about the "Kindergarten from Home" programme

\begin{tabular}{|c|c|c|}
\hline Categories & $\begin{array}{c}\text { Number of } \\
\text { responses (\%) }\end{array}$ & Example of a response \\
\hline $\begin{array}{l}\text { Usefulness, } \\
\text { organization }\end{array}$ & $151(31 \%)$ & $\begin{array}{l}\text { "Nicely thought out and useful, so that the child is up to date with } \\
\text { activities and is familiar with the curriculum of the kindergarten." }\end{array}$ \\
\hline Educational purposes & $122(25 \%)$ & $\begin{array}{l}\text { "Everything was great, and it helped us actually spend quality time } \\
\text { together, and learn a lot of new things. The child has become more } \\
\text { responsible in completing the tasks." }\end{array}$ \\
\hline $\begin{array}{l}\text { Connection to the } \\
\text { kindergarten group }\end{array}$ & $141(29 \%)$ & $\begin{array}{l}\text { "I loved the idea, we were enabled to continue the activities with } \\
\text { the child, we are connected with other friends and parents." }\end{array}$ \\
\hline $\begin{array}{l}\text { Irreplaceability of the } \\
\text { kindergarten work in } \\
\text { normal circumstances }\end{array}$ & $74(15 \%)$ & "It cannot be as effective as kindergarten in the kindergarten." \\
\hline Total & 488 (100\%) & \\
\hline
\end{tabular}

Table 9 shows us that the greatest percentage of the parents' answers (31\%) refer to the category "usefulness, organization" for a general evaluation of the "Kindergarten from Home" programme. A somewhat smaller percentage (29\%) refers to the categories "connection to the kindergarten group and educational purposes" (25\%). 


\section{Discussion}

The most pleasurable activities for the children in the "Kindergarten from Home" programme were the following ones: spending time together with parents, followed by activities in the yard, nature, activities for motor skills, music and drama activities, activities for developing certain graphomotor skills and the like. Next, a quarter of the children independently initiated activities in the "Kindergarten from Home" programme. More than half of the children are motivated to continue the "Kindergarten from Home" programme. These results are in line with the findings which point out that the potential cause of partial or sporadic student engagement may be the idea that this type of learning is too challenging or uninteresting. Children and youth may lose all interest in learning if the very idea of learning from home presents some difficulty, or is not encouraging enough. This can also happen if they are separated from their peers (Smith, 1993).

The parental assessment of the usefulness and interestingness of the "Kindergarten from Home" programme is in line with the results of previous research (Bradley \& Corwyn, 2002) which suggests that children acquire the most basic knowledge either at home or in kindergarten. The importance of family support systems in times of pandemic is also discussed by Xafis who points out that if these systems do not exist, fail or stop working, there can be extremely negative and long-term consequences for the youngest (Xafis, 2020). Children themselves are extremely vulnerable because meeting their most basic needs depends on adults.

It can be seen from the data (especially from the parents' answers): that the "Kindergarten from Home" programme is based primarily on the ideas and suggestions of the educators; that the activity proposals were understood as tasks given to the children; it can be seen from the parents' answers that the proposed activities have a didactic-educational function; parents' comments indicate that some of them wanted more ideas for play and meaningful time spent outdoors, fewer tasks and the like.

From the parents' answers regarding the reasons for their non-involvement in the "Kindergarten from Home" programme, we can see that the parents organized their time in accordance with their own needs and dynamics. We can assume that parents would have been more involved in the "Kindergarten from Home" programme if there had been fewer suggested tasks and activities. From the general evaluation of the "Kindergarten from Home" programme, we can conclude that the support that the parents received was significant and educational. However, due to the entire work schedule of the parents who worked even during the state of emergency, the irreplaceability of the work of the kindergarten in normal circumstances is emphasized.

We can say that the above mentioned evaluation of the "Kindergarten from Home" programme is in line with the claim of UNESCO (2020) that formal education - whether on-site or remote - provides the basic knowledge and skills necessary for further growth and development of children. Also, Biemiller \& Boote believe that many formal education opportunities are not available due to the closure of schools and institutions caused by the COVID-19 virus epidemic (Biemiller \& Boote, 2006). However, on the other hand, reading to children daily is a low-tech strategy for preventing certain negative consequences caused by the schools' and kindergartens' closure due to the COVID-19 virus epidemic, while strengthening family ties. 
The critical assessment of the "Kindergarten from Home" programme is focused on: too many offered activities, lack of materials for making suggested games, frequent sending of messages in Viber groups, and that children's works are a product of parental work (the children's answers showed that they want joint games and activities with their parents, as well as to be outside).

The parents made suggestions for improving the functioning of the "Kindergarten from home" programme, which referred to: the formation of a digital platform that would enable "online" communication and cooperation with the entire peer group, quality and innovative activities, and outdoor activities. Parents emphasized the importance and irreplaceability of the work of the kindergarten in normal circumstances. The parents' suggestions are focused on innovation related to connecting with the child's kindergarten group, which would contribute to a sense of belonging. The result is in line with the basic human need to belong and to be accepted in a certain group, more precisely, satisfying the affiliative and gregarious motive. Smith (1993) believes that children would be motivated to participate in activities because they are connected to their peers.

\section{Conclusion}

The results of the research "Evaluation of the "Kindergarten from Home" Programme during the COVID-19 Pandemic" should be seen as a critical review and development of programme quality that would be more in line with the expressed needs of children and families and the concept of programme basics, more participatory and less didactic. In the following period, it is necessary that the educators and nurses-educators evaluate the programme "Kindergarten from Home", and work on improving this type of kindergarten work programme.

The results of this research can be used as a contribution to further theoretical research, but also in understanding the functioning of the programme "Kindergarten from Home", when implementing elements of this programme as part of the programme of preschool institutions in order to improve them.

Certainly, one should keep in mind the circumstances that may have affected the results obtained, such as: little time that educators and nurses-educators had to prepare the "Kindergarten from Home" programme, organizational problems at the national, local and preschool level, poor training of educators and nurses-educators in using online communities of support and exchange with families, as well as the social conditions in which the programme was implemented. In addition, it should be taken into account that the research questionnaire used is not standardised, but was constructed for the needs of the research. On the other hand, we assume that if the programme was implemented in other circumstances, the organization of preschool institutions and the preparation of educators and nurses-educators for the online community of support and exchange with families would give better results. 
From the aspect of the organization of preschool institutions, the "Kindergarten from Home" programme is generally cheaper due to the lower costs required for its implementation. "Kindergarten from Home" is the only way to provide support to families and children in remote and/or rural areas who do not have the opportunity to be part of the preschool educational system. Today, the "Kindergarten from Home" programme in unforeseen circumstances represents an innovative approach in the system of preschool education that ensures its sustainability. However, it is important to point out the irreplaceability of kindergarten work in normal circumstances, especially for families where both parents are employed, single parents and parents raising children in unstimulating environments.

In relation to the results of the research and the recognized advantages of the programme, recommendations for improving the functioning of the "Kindergarten from Home" programme would be aimed at creating a digital online platform that would allow more active participation and exchange between children prevented from attending kindergarten, with kindergarten group members and educators, which would contribute to a more efficient and creative functioning of the programme.

\section{References}

Biemiller, A., \& Boote, C. (2006). An effective method for building meaning vocabulary in primary grades. Journal of Educational Psychology, 98(1), 44-62. https://doi.org/10.1037/0022-0663.98.1.44

Bradley, R. H., \& Corwyn, R. F. (2002). Socioeconomic status and child development. Annual Review of Psychology, 53(1), 371-399. https://doi.org/10.1146/annurev.psych.53.100901.135233

Castles, A., Rastle, K., \& Nation, K. (2018). Ending the reading wars: Reading acquisition from novice to expert. Psychological Science in the Public Interest, 19(1), 5-51. https://doi. org/10.1177/1529100618772271

Cameron, L., \& Tenenbaum, R., H. (2021). Lessons from developmental science to mitigate the effects of the COVID-19 restrictions on social development. Group Processes \& Intergroup Relations, 24(2), 231-236.

Ernest, J. M., Causey, C., Newton, A. B., Sharkins, K., Summerlin, J., \& Albaiz, N. (2014). Extending the global dialogue about media, technology, screen time, and young children. Childhood Education, 90(3), 182-191. https://doi.org/10.1080/00094056.2014.910046

Goldschmidt K. (2020). The COVID-19 Pandemic: Technology use to Support the Wellbeing of Children. Journal of pediatric nursing, 53(1), 88-90. https://doi.org/10.1016/j.pedn.2020.04.013

Marković, M., Stanisavljević-Petrović, Z., \& Mamutović, A. (2019). Informisanost roditelja o oblastima rada stručnih saradnika u predškolskim ustanovama. Nastava i vaspitanje, 68(1), 89-106. https:// doi.org/10.5937/nasvas1901089M

Minić, V., \& Kompirović, T. (2014). Funkcije i problemi savremene porodice u vaspitanju dece ranog uzrasta. Zbornik radova Učiteljskog fakulteta u Prizrenu - Leposavić, 8(1), 27-40. https://doi.org/14529343/2014/1452-93431408027M 
Neuman, S. B., Copple, C., \& Bredekamp, S. (2000). Learning to read and write: Developmentally appropriate practices for young children. Washington, D.C: National Association for the Education of Young Children.

Plowman, L. (2014). Researching young children's everyday uses of technology in the family home. Interacting with Computers, 27(1), 36-46. https://doi.org/10.1093/iwc/iwu031

Prensky, M. (2001). Digital natives, digital immigrants. On the Horizon, 9(5), 1-6. https://doi. org/10.1108/10748120110424816

Predškolstvo (2020). Predškolsko vaspitanje i obrazovanje u vreme epidemije COVID-19. Beograd: Ministarstvo prosvete, nauke i tehnološkog razvoja. Retrieved from http://www.mpn.gov.rs/wpcontent/uploads/2020/03/pred\%C5\%A1 kolsko vest_pdf.pdf

Rose, E., Lehrl, S., Ebert, S., \& Weinert, S. (2018). Long-term relations between children's language, the home literacy environment, and socioemotional development from ages 3 to 8 . Early Education and Development, 29(3), 342-356. https://doi:10.1080/10409289.2017.1409096

Smith, A. B. (1993). Early childhood educare: Seeking a theoretical framework in Vygotsky's work. International Journal of Early Years Education, 1(1), 47-62. https://doi.org/10.1080/0966976930010105

Stepanović, S. (2020). Uticaj pandemije virusa korona na obrazovanje. Nastava i vaspitanje, 69(2), 183-196. https://doi.org/10.5937/nasvas2002183S

Tamis-LeMonda, C. S., Luo, R., McFadden, K. E., Bandel, E. T., \& Vallotton, C. (2019). Early home learning environment predicts children's 5th grade academic skills. Applied Developmental Science, 23(2), 153-169. https://doi.org/10.1080/10888691.2017.1345634

UNESCO (2020). COVID-19 Educational Disruption and Response. Retrieved from https://en.unesco. org/covid19/ education response

Wang, G., Zhang, Y., Zhao, J., Zhang, J., \& Jiang, F. (2020). Mitigate the effects of home confinement on children during the COVID-19 outbreak. Lancet, 395(10228), 945-947. https://doi.org/10.1016/ S0140-6736(20)30547-X

World Bank. (2020). The COVID-19 pandemic: Shocks to education and policy responses. https://www. worldbank.org/en/topic/education/publication/the-covid19-pandemic-shocks-toeducationand-policy-responses

Xafis, V. (2020). "What is inconvenient for you is life-saving for me": How health inequities are playing out during the COVID-19 pandemic. Asian Bioethics Review, 12(2), 223-234. https://doi.org/10.1007/ s41649-020-00119-1

Zakon o osnovama sistema obrazovanja i vaspitanja (2020). Službeni glasnik Republike Srbije, br. 6/2020.

Zero to Three. (2020). How COVID-19 is impacting child-care providers. Retrieved from https://www. zerotothree.org/resources/3398-howcovid-19-is-impacting-child-care-providers

Примљено: 20. 02. 2021.

Коригована верзија примљена: 09. 05. 2021.

Прихваћено за штампу: 20. 05. 2021. 


\title{
Евалуација програма „Вртић од куће“ током пандемије COVID-19
}

\author{
Александра Пајевић \\ Предшколска установа Ђурђевдан, Крагујевац, Србија \\ Мирсен Фехратовић \\ Студијски програм Психологија, Катедра филозофских наука, \\ Државни универзитет Нови Пазар, Србија
}

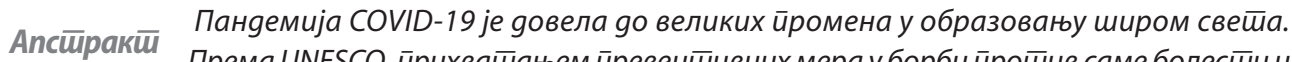

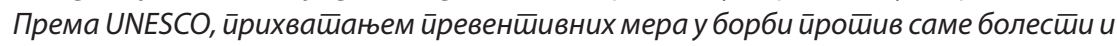
юеної ширења, йреко 1,5 милијарgи ученика и gече искусило је йреки формалної образовања шйо је био и исйовремени шок за све образовне сисшеме. Међунароgна зяравсиввена криза је

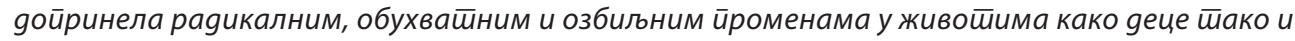

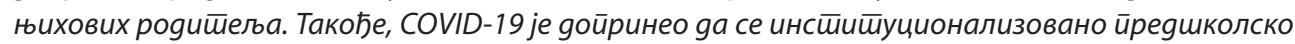

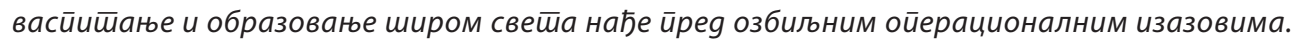

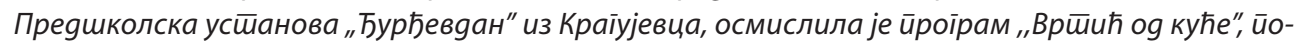
шйујући иррава деце и основне йринцийе васииитања и образовања. Емйиријско исйраживање

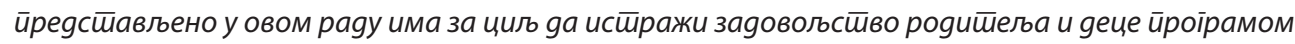

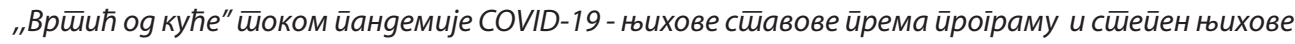
йарйицийације. Узорак је био сачињен оg 488 роgишееља и 302 gейейа. Резулйайи су йоказали

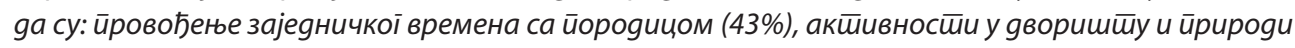

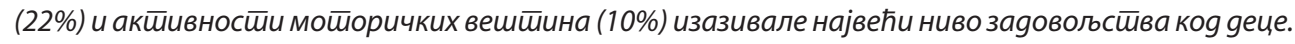

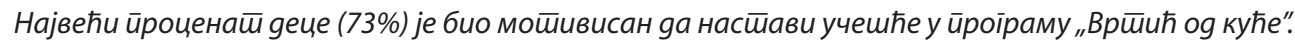

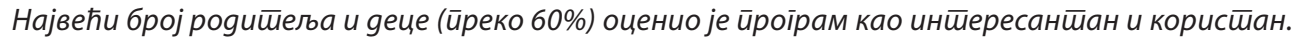

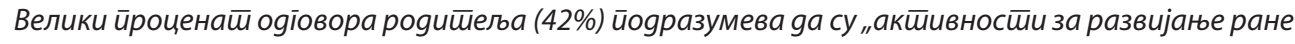

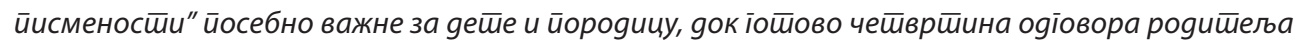

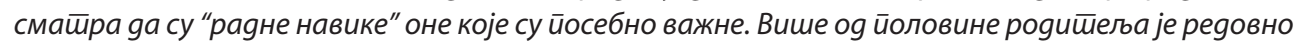

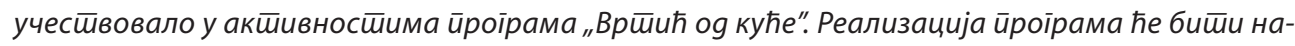
сйављена са циљем ӣружањ а ӣоgршке васииитану и образовању gеце и йороgица, чак и каgа се

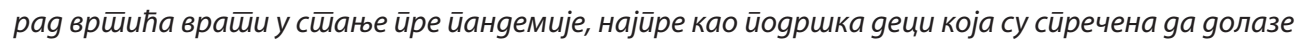
уврйић.
\end{abstract}

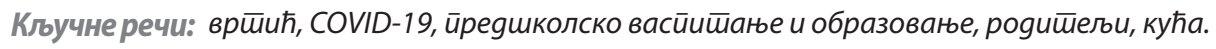




\title{
Оценка программы “Детский сад из дома" во время пандемии COVID-19
}

\author{
Александра Паевич \\ Дошкольное учреждение «Джурджевдан», Крагуевац, Сербия \\ Мирсэн Фехратович \\ Учебная программа Психология, кафедра философских наук, Новипазарский \\ государственный университет, Нови Пазар, Сербия
}

\begin{abstract}
Резюме Пандемия COVID-19 привела к серьезным изменениям в образовании во всем мире. По
данным ЮНЕСКО, в прочессе адаптирования превентивных мер в борьбе с самой болезнью и ее распространением, более 1,5 миллиарда учеников и детей столкнулись с перебоями в формальном образовании, что одновременно привело в шоковое состояние все системы образования. Международный кризис в области здравохранения привел крадикальным, далеко идущим и серьезным изменениям в жизни детей и их родителей. Кроме того, COVID-19 внес свой вклад в систему дошкольного воспитания и образования, столкнувши ее с серьезными оперативными проблемами. Детское учреждение «Джурджевдан» из г. Крагуевац разработало программу «Детский сад из дома», с учетом прав детей и соблюдением основных принципов воспитания и образования. Целью эмпирического исследования, представленного в данной статье, является изучение удовлетворенности родителей и детей программой "Детский сад из дома» во время пандемии COVID-19 для определения поведения и масштабов участия детей и родителей. В выборку вошли 488 родителей и 302 ребенка. Результаты показали, что такие занятия как: времяпровождение с семьей (43\%), времяпровождение во дворе и на природе (22\%), двигательная активность (10\%) вызвали максимальный уровень удовлетворения у детей. Наибольший прочент детей (73\%) был мотивирован к продолжению участия в программе «Детский сад из дома». Максимальное число родителей и детей (свыше 60\%) оценили высшей оценкой занимательность и полезность данной программы. Большой прочент ответов родителей (42\%) сходится в том, что «мероприятия по развитию грамотности в раннем возрасте» особенно важны для ребенка и семьи, а в то же время почти чертверть ответов родителей указывает на то, что «рабочие навыки» особенно важны. Более половины родителей регулярно участвовали в мероприятиях программы «Детский сад из дома». Программа будет продолжена с целью оказания поддержки в воспитанию и образованию детей и их семей даже когда работа детских садов веренется в режим до пандемии, и предназначена детям, которые по какой-то причине лишены возможности посещать детский сад.
\end{abstract}

Ключевые слова: детский сад, COVID-19, дошкольное воспитание и образование, родители, дом. 